\title{
Need-analysis on Importance of Health Education Assessment Module for Lower Primary Teachers in Classroom-based Assessment
}

\author{
Kumaran Gengatharan ${ }^{1, *}$, Azali Bin Rahmat ${ }^{1}$, Szarmilaa Dewie Krishnan ${ }^{2}$ \\ ${ }^{1}$ Faculty of Sports Science and Training, Universiti Pendidikan Sultan Idris, Malaysia \\ ${ }^{2}$ Faculty of Education, National University of Malaysia, Malaysia
}

Received March 28, 2020; Revised May 28, 2020; Accepted June 4, 2020

Copyright $\mathrm{C} 2020$ by authors, all rights reserved. Authors agree that this article remains permanently open access under the terms of the Creative Commons Attribution License 4.0 International License

\begin{abstract}
This study aims to develop a Health Education assessment module in the classroom for lower primary teachers. The objective of this study is to identify the importance of the assessment module of Health Education in classroom assessment for lower primary teachers. The design used in this study is the design and development research method, which has three phases. The first phase is to analyze the needs, the second phase is design and development, and the third phase is the implementation and assessment of the module. The instrument used in this phase is the questionnaire to identify the importance of assessment material, which is the assessment module for teachers who teach Health Education for lower primary class students in classroom-based assessment. Analysis towards the data of this study was made by using 'SPSS' version 22. Research findings show the importance and the need to develop the assessment module of Health Education for lower primary teachers in conducting the classroom-based assessment. In conclusion, results prove that the Health Education assessment module development is very imperative and essential for teachers in teaching Health Education subject for lower primary students. Not that only, data obtained from the questionnaire show that Health Education teachers felt more comfortable to teach Health Education using the module comparatively as the workload has decreased. The analysis also evidenced that 93.4 percent of teachers think that they can retain the Health Education assessment module as an assessment record. On the whole, this research will be an asset to Malaysia curriculum development.
\end{abstract}

Keywords Health Education, Assessment Module, Classroom-based Assessment

\section{Introduction}

There are two types of assessments in Malaysia, that is, exam orientated assessment and school-based assessment. Exam orientated assessment was carried out by the Malaysian Examinations Board and school-based assessment was carried out by the school. The assessment implementation is in line with the classification made by Shepard L.A (2000) [1], whereby the exam orientated assessment is known as external assessment in the form of summative while the school-based assessment is also known as internal assessment in the way of formative. According to Lembaga Peperiksaan, Kementerian Pelajaran Malaysia (2011) [2], emphasis rendered overly on academic achievement can infuse stress to the teachers, parents, and pupils. Pressure towards the teacher in completing the syllabus causes the assessment to be ignored and less effective in teaching and learning. Thus, effort should be taken to lift the teaching profession as well as enhance the quality of teaching and learning. Furthermore, the Lembaga Peperiksaan, Kementerian Pelajaran Malaysia (2011) [2], has also stated that developed countries have changed their education assessment system. There is also a claim that our national education system is too dependent on examination being exam-oriented. As part of the educational transformation program dated 17 December 2010, the cabinet of ministers had agreed for the implementation of school-based assessment in school.

School-based assessment widely known as SBA refers to an attempt to grow a person holistically through prominence towards mastery of knowledge, intellectual model, progressive attitude as a habit of teaching moral principles, ethics and morality as described in the Blueprint for Malaysian education, the national integrity plan that aspired as our national mission. SBA was implemented at 
primary school in the year 2011 and was introduced at the secondary school level in 2012. It was performed based on Surat Siaran Lembaga Peperiksaan Bil 3/2011 [3]. According to the letter, SBA is an assessment system used to ensure the pupil's achievement without being assessed solely on examination. SBA also involves assessment comprehensively (holistic) towards success and pupils learning development through four components, namely school assessment, physical activity assessment, sports and co-curriculum, psychometric assessment, and exam orientated. In 2014, the Ministry of Education (MOE) had to stabilize SBA's implementation through further revision to become more friendly teachers as in Surat Pekeliling Lembaga Peperiksaan Bil. 1/2014 [4]. In 2016, one of the SBA's components, namely school-based assessment, was changed named to classroom-based assessment.

According to Bahagian Pembangunan Kurikulum (2018) [5], school-based assessment retains all school assessment concept and involve pupil's control level of determination in every subject. Teacher plays a vital role in implementing SBA with a set of learning objectives which aims to increase pupil's learning through formative assessment termed as assessment for learning, assessment as learning and assessment of learning.

Bahagian Pembangunan Kurikulum, (2018) [5], explained that assessment for learning is referred to as formative assessment. Assessment as learning happens when the pupil makes reflection and evaluates the respective development of learning. This enables those understanding of their purpose of learning and realizes what they should do to achieve learning objectives. In contrast, assessment of learning, happened at the end of a stipulated period, subject or area of education. Usually, assessment occurs in the summative form of test Bahagian Pembangunan Kurikulum, (2018) [5].

Classroom assessment becomes more significant and compulsory to all citizens when the former Minister of Education, Dr. Maszlee Malik, announced examination to be revoked for pupils on 31 October 2018. His statement has been enforced according to Surat Siaran KPM Bil 14/2018; Pemansuhan Amalan Peperiksaan Pertengahan dan Akhir Tahun Murid Tahap 1 [6].

\section{Literature Review}

Researchers had used modules in various fields and studies in the past. Habibah (1991) [7], used a module to help the pupil who had a motivation problem in learning, proved that module usage could enhance pupil's performance in learning. Her opinion is parallel with Shahrom and Yap (1991) [8], which states that the module has assessment features enabling the student to get feedback on comprehension level and their achievement in learning.

Shahril Effendi Bin Ibrahim (2017) [9], has provided an assessment module on pupil development in pre-school. This is to enhance skills, instill confidence, and form self-concept that is positive in them that they managed to be in the existing environment and prepared to handle challenges and responsibility at primary school later. To ensure objective achieved, assessment should proceed to evaluate the child's development from time to time with assessment module usage. Assessment proposed is the assessment by formative and authentic through the lesson and daily learning through modular usage.

Meanwhile, Norlly Mohd Isa and Hamimah Abu Naim (2013) [10], implemented a school-based (MoPBeS) assessment module construction requirement study for science subjects. This study aims to study MoPBeS's need for the dynamic topic in Form 2 Science subject. MoPBeS is an assessment module that was focusing on assessment based on assignment, assessment in learning, and assessment for learning. This study was carried out in 3 phases. The first phase is the analysis document carried out towards studies last related assessment effectiveness in the classroom (classroom assessment). The second phase is the analysis of the dynamic subject in Form Science subject 2. The third phase is a questionnaire shaped study aimed to observe teacher's views on MoPBeS need to improve SBA implementation in teaching and learning in the classroom. This need study result is essential to ensure construction and MoPBes assessment that will be conducted in giving impact to SBA implementation.

Besides, research on assessment module learning for 'attack category games' in Physical Education year four done by Liza Saad, Julismah Jani, Azali Rahmat, and Salimin Norkhalid [11], in the year 2016 discussed on validity and learning assessment module credibility in Physical Education. This study used a holistic instrument to evaluate the standard performance of students for 'attack category' games. The research instrument of this study being built based on four primary sources, namely, 'Buku Panduan Pengajaran Pendidikan Jasmani dan kesihatan,' 'Dokumen Standard Kurikulum dan pentaksiran' Physical and Health Education textbook, and Malaysia Education Blueprint 2013-2025. The assessment module shows the learning for 'attack category' games. That is, mastery of student achievement of all three learning domains, and it shows a strong tie. Based on the assessment module, this learning is suitable to be used as an instrument standard to evaluate the student's mastery level for 'attack category' games in Physical Education.

\section{Methodology}

\subsection{Research Design}

Generally, this study employs design and development research method (DDR) introduced by Ritchey and Klien 
(2007) [12]. According to Ritchey and Klien (2007) [12], this method is very appropriate to be used in research with a character final decision like a model, module, framework, taxonomy and other studies that will produce something innovative. There are three phases in DDR. It consists of needs analysis, design and development, and evaluation phases. Every phase is implemented by using a different approach from the study method, sampling, procedure, instrument protocol, and analysis data. For the study, the researcher uses the first phase, namely, needs analysis, to obtain data on the Health Education assessment module for lower primary teachers in the classroom-based assessment.

\subsection{Population and Research Sample}

The population of this study is teachers who teach Health Education subject for lower primary students in Kedah state. According to the Kedah Education Department (2018) [13], population of teachers who teach Health Education in Kedah state is 1198. According to Krejcie \& Morgan's (1970) [14], sample size the researcher has chosen 291 Health Education teachers as a research sample for the need analysis phase.

\subsection{Research Instrument}

The research instrument used in this phase is the questionnaire. It is to gain data regarding the importance of the Health Education assessment module for lower primary teachers in the classroom-based assessment. This questionnaire is divided into two parts, namely Part A containing the respondent's background and Part B, about the importance of the Health Education assessment module. Part B will be analyzed using percentage, mean, and standard deviation.

\section{Results}

\section{Part A of the questionnaire:}

In the questionnaire, this section is labeled as part $\mathrm{A}$ which contains several questions regarding the respondent's background, such as gender, ethnicity, and teaching experience of Health Education subjects in schools.

Table 1. Gender

\begin{tabular}{|c|c|c|}
\hline Gender & Frequency & Percentage (\%) \\
\hline Male & 89 & 31.0 \\
Female & 202 & 69.0 \\
Total & 291 & 100 \\
\hline
\end{tabular}

Table 1 shows the gender of the respondent of the research. This research contains 89 male respondents and 202 female respondents. It shows most respondents comprising female teachers of 69 percentage, and this followed by 31 percentage of male teachers respondents.

Table 2. Ethnicity

\begin{tabular}{|c|c|c|}
\hline Kaum & Frequency & Percentage (\%) \\
\hline Malay & 119 & 40.9 \\
Indian & 104 & 35.7 \\
Chinese & 57 & 19.6 \\
Other ethnic & 11 & 3.8 \\
Total & 291 & 100 \\
\hline
\end{tabular}

Table 2 shows the ethnicity of the respondent. The respondent consists of Malay, Indian, Chinese, and other ethnic groups. The Malay-related teachers at $40.9 \%$ had become the primary respondent in this study, followed by the Indian teacher, 35.7\%, and then the Chinese ethnic teacher, at $19.6 \%$. Besides, teachers of different races at $3.8 \%$ also participated in the analysis of this requirement.

Table 3. The service range of teaching Health Education

\begin{tabular}{|c|c|c|}
\hline Service range & Frequency & Percentage (\%) \\
\hline 1 to 4 year & 48 & 16.5 \\
5 to 10 year & 55 & 18.9 \\
11 year above & 188 & 64.6 \\
Total & 291 & 100 \\
\hline
\end{tabular}

Table 3 shows the range of teaching of Health Education subject has been categorized into service range from 1 to 4 years, 5 to 10 years, and 11 years above. Most of the respondents have teaching experience in Health Education 11 years above, which is $64.6 \% .18 .9 \%$ of the teachers have 5 to 10 years of teaching experience and followed by $16.5 \%$, which is 1 to 4 years of experience.

\section{Part $B$ of the questionnaire:}

In the questionnaire, this section is labeled as part B, which contains several questions regarding the importance of the Health Education assessment module for lower primary teachers.

Table 4. Need-analysis on importance of Health Education assessment module for lower primary teachers in the classroom-based assessment.

\begin{tabular}{|l|c|}
\hline \multicolumn{1}{|c|}{ Question } & Percent \\
\hline $\begin{array}{l}\text { Do you think that burden decreases if there is a module } \\
\text { prepared for lower primary Health Education teacher? }\end{array}$ & $90.5 \%$ \\
\hline $\begin{array}{l}\text { Do you think that only a few types of exercise } \\
\text { book/assessment material are for Health Education in } \\
\text { the market? }\end{array}$ & $91.6 \%$ \\
\hline $\begin{array}{l}\text { Do you think that there is a need to develop an } \\
\text { assessment module for Health Education subject? }\end{array}$ & $92.7 \%$ \\
\hline $\begin{array}{l}\text { Do you think that the Health Education assessment } \\
\text { module may be stored as an assessment record? }\end{array}$ & $93.4 \%$ \\
\hline $\begin{array}{l}\text { Do you feel more comfortable to teach Health } \\
\text { Education if supplied with assessment material to } \\
\text { implement classroom-based assessment? }\end{array}$ & $95.1 \%$ \\
\hline
\end{tabular}

Table 4 discusses Part B in the questionnaire on the importance of the Health Education assessment module for lower primary teachers in classroom-based assessment in terms of percentage. There are five questions in that section related to the need for an assessment module for 
Health Education. Analysis confirms that overall, 92.7 percent with 270 Health Education teachers from 291 Health Education teachers agreed that there is a need to develop an assessment module for Health Education subject. This is due to less Health Education material in the market, which denotes 91.6 percent, and assessment material bought from the supplier has no standard in accommodating for learning purposes. Not only that, but data obtained from the questionnaire also shows $95.1 \%$ of teachers feel more comfortable teaching Health Education using the module comparatively as the workload will be decreased $(90.5 \%)$. The analysis also evidenced that $93.4 \%$ of teachers think that they can retain the Health Education assessment module as an assessment record.

Table 5. Descriptive statistics on the importance of the Health Education assessment module for lower primary teachers in the classroom-based assessment.

\begin{tabular}{|c|c|c|c|}
\hline ITEM & $\mathbf{M}$ & SD & Level \\
\hline $\begin{array}{l}\text { Do you think that burden will decrease } \\
\text { if there is a module prepared for lower } \\
\text { primary Health Education teacher? }\end{array}$ & 4.31 & .73 & $\begin{array}{l}\text { Very } \\
\text { High }\end{array}$ \\
\hline $\begin{array}{l}\text { Do you think that only a few types of } \\
\text { exercise book/assessment material are } \\
\text { for Health Education in the market? }\end{array}$ & 4.36 & .69 & $\begin{array}{l}\text { Very } \\
\text { High }\end{array}$ \\
\hline $\begin{array}{l}\text { Do you think that there is a need to } \\
\text { develop an assessment module for } \\
\text { Health Education subject? }\end{array}$ & 4.41 & .62 & $\begin{array}{l}\text { Very } \\
\text { High }\end{array}$ \\
\hline $\begin{array}{l}\text { Do you think that the Health Education } \\
\text { assessment module may be stored as } \\
\text { an assessment record? }\end{array}$ & 4.48 & .68 & $\begin{array}{l}\text { Very } \\
\text { High }\end{array}$ \\
\hline $\begin{array}{l}\text { Do you feel more comfortable to teach } \\
\text { Health Education if supplied with } \\
\text { assessment material to implement } \\
\text { classroom-based assessment? }\end{array}$ & 4.56 & .74 & $\begin{array}{l}\text { Very } \\
\text { High }\end{array}$ \\
\hline
\end{tabular}

Table 5 shows the evidential need for the Health Education assessment module in mean (M), standard deviation according to the Likert Scale. It is categorized into five scales being 1 (Strongly do not agree), 2 (Do not agree), 3 (Slightly agree), 4 (Agree), and 5 (Strongly agree). The mean score guide was adapted from Jainabee and Jamil (2009) [15], whereby the statistical data indicates very low (1.00-1.80), low (1.81-2.60), medium (2.61-3.40), high (3.41-4.20) and very high (4.21-5.00). On the whole, the mean score of all questions is very high. Question recorded agreeable score that is very high whereby teacher's burden will decrease if there is a module prepared for lower primary Health Education teacher $(\mathrm{M}=4.31 ; \mathrm{SD}=.73)$, exercise book/assessment material for Health Education noted very few in the market $(\mathrm{M}=4.36$; $\mathrm{SD}=.69)$, there is need to develop assessment module for Health Education subject $(\mathrm{M}=$ 4.41; $\mathrm{SD}=.62$ ), Health Education assessment module may be highlighted as assessment record $(\mathrm{M}=4.48 ; \mathrm{SD}=.68)$, and finally, teachers feel more comfortable to teach Health Education if supplied with assessment material to implement classroom-based assessment. $(\mathrm{M}=4.56$; $\mathrm{SD}$ $=.74$ ).

\section{Discussion}

Thus, overall retrieval research shows undoubtedly there is a need to develop a Health Education assessment module for teachers in teaching Health Education implementing SBA for lower primary pupils. According to Norazilawati, Noorzeliana, Mohd Sahandri, and Saniah (2015) [16], 66.7 percent of teachers do not build any instrument due to time constraints and numerous loads. Assessment module development will reduce the teacher's burden if the module is prepared for pupils in learning Health Education subject, and the teacher will also be more comfortable if supplied with assessment materials like assessment module.

Although assessment materials on Health Education subject are less in the market, according to Othman, Siti Esah, Ahmad Fuaad, Azali, and Omar (2013) [17], most teachers who teach Health Education and Physical Education subject are still amateurish in constructing assessment items. Hence teachers usually buy exercise books or assessment materials from the supplier upon verifying validity issues. With the assessment module being developed for Health Education that follows the learning standard and annual lesson plan, teachers need not buy assessment materials. They can use it as an assessment record as this is also an effort to fulfill teachers' requests in teaching Health Education for the lower primary.

Not only that, the module has been developed in various fields, but less study has been performed concerning assessment module development for Health Education subject for SBA because most of the study focuses on core subjects only. Therefore, this study is immensely useful and essential, which will become an asset to a large group of Health Education teachers who teach the lower primary in conducting the classroom-based assessment.

\section{Conclusions}

The findings of this study will give implications to various parties, especially to the schools and students. Students can comfortably and confidently utilize the Health Education assessment module. Moreover, the assessment module can also be shown as an assessment record for all parents who would want to know their children's development in Health Education subject. Apart from that, the assessment module will also involve students directly in implementing the government's policy and the aspiration of the State Education Department. In conclusion, results prove that the Health Education assessment module development is very imperative and essential for teachers in teaching Health Education subject for lower primary students. 


\section{Acknowledgments}

The author would like to thank lecturers from Universiti Pendidikan Sultan Idris, who provided insight and expertise that is significantly assisted in the research. However, they may not agree with all of the interpretations/conclusions of this paper. The author also would like to thank Prof Madya Dr. Azali Bin Rahmat for assistance with methodology, and Mr.Hisahamudin, Senior Lecturer, Universiti Pendidikan Sultan Idris for comments that significantly improved the manuscript. We are also immensely grateful to Ms.Szarmilaa Dewie Krishnan, Universiti Kebangsaan Malaysia, for her comments on an earlier version of the script. However, any errors are our own and should not tarnish the reputations of these esteemed people.

\section{REFERENCES}

[1] Shepard, L. A. The Role of Assessment in a Learning Culture. Educational researcher, 29 (7), 14, 2000.

[2] Lembaga Peperiksaan, Kementerian Pelajaran Malaysia, [Examination Board, Ministry of Education, Malaysia], 2011.

[3] Surat Siaran Lembaga Peperiksaan Bil 3/2011- Pemakluman Pentaksiran Berasakan Sekolah (PBS) di sekolah Rendah dan Menengah Rendah, Kementerian Pelajaran Malaysia, [Examination Board Circular Vol. 3/2011- School-Based Assessment in Primary and Secondary School Education, Ministry of Education Malaysia], 2011.

[4] Surat Pekeliling Lembaga Peperiksaan Bil. 1/2014Penambahbaikan Pentaksiran Berasaskan Sekolah (PBS). Kementerian Pelajaran Malaysia, [Examination Board Circular Vol. 1 / 2014- Improvement of School-Based Assessment, Ministry of Education Malaysia], 2014.

[5] Bahagian Pembangunan Kurikulum- Panduan Pelaksanaan Pentaksiran Bilik Darjah, Kementerian Pelajaran Malaysia, [Curriculum Development Division- Implementation Guide of Classroom Assessment, Ministry of Education Malaysia], 2018.
[6] Surat Siaran KPM Bil 14/2018- Pemansuhan Amalan Peperiksaan Pertengahan dan Akhir Tahun Murid Tahap 1, Kementerian Pelajaran Malaysia, [Ministry of Education Circular Vol 14/2018- Abolition of Midterm and End-Year Examinatiom for Lower Primary Student's], 2018.

[7] Habibah Ali, Kesan Latihan Motivasi Pencapaian ke atas Pelajar-Pelajar Universiti, Jabatan Psikologi, Universiti Kebangsaan Malaysia, 1991.

[8] Shahrom Noordin \& Yap, K.C. Ke arah mengindividukan pengajaran menerusi pengajaran bermodul. Jurnal Pendidikan Guru, 7, 89-107, 1991.

[9] Shahril Effendi Bin Ibrahim, Modul Pentaksiran Perkembangan Murid di Prasekolah, Online available from Open University Malaysia Digital Library Portal, 2017.

[10] Norlly Mohd Isa dan Hamimah Abu Naim, Kajian Keperluan Pembinaan Modul Pentaksiran Berasaskan Sekolah Bagi Tajuk Dinamik Dalam Mata Pelajaran Sains Tingkatan 2, 2nd International Seminar on Quality and Affordable Education, Fakulti Pendidikan, Universiti Teknologi Malaysia, 2013.

[11] Liza Saad et al., Validity and Reliability of Learning Assessment Instruments for Invasion, International Journal of Social and Related Science, Vol. 1, No.2 PP. 7-11, 2106.

[12] Richey, R. C., \& Klein, J. D., Design, and Development Research. Mahwah, NJ: Lawrence Erlbau Associates Publisher 2007.

[13] Kedah Education Department. Student's and Teacher's Statistics, 2018.

[14] Krejcie, R. V., \& Morgan, D. W., Determining sample size for research, Educational and Psychological Measurements, 30, 607-610, 1970.

[15] Jainabee Kassim \& Jamil Ahmad,. Kualiti Kepimpinan Pengetua Sekolah-sekolah Menengah Zon Selatan, Seminar Nasional Pengurusan dan Kepimpinan Pendidikan Ke-16, Malaysia, 2009.

[16] Norazilawati Abdullah et al., Penilaian Pelaksanaan Pentaksiran Berasaskan Sekolah, (PBS) Dalam Kalangan Guru Sains, Jurnal Pendidikan Sains \& Matematik Malaysia, Vol.5, No.1, 2015.

[17] Othman et al., Thrombosis and Haemostasis, Journal of Physical Education, 2013. 